\title{
Dos pacientes con microcalcificaciones testiculares (MT)
}

Pastor Navarro H, Donate Moreno MJ, Carrión López P, Giménez Bachs JM, Pastor Guzmán JM, Segura Martín M, Lorenzo Romero JG, Salinas Sanchez A, Virseda Rodríguez JA.

Servicio de Urologia. Hospital General Universitario. Albacete

Actas Urol Esp. 2008;32(2):268

Caso 1

Mostramos la ecografia de ambos testes de paciente de 40 años, padre de dos hijos, que consultó por orquialgia leve, en la que se aprecian microcalcificaciones múltiples bilaterales. Seguimiento durante los cuatro últimos años, con ecografia y marcadores testiculares cada seis meses, sin aparentes cambios ecográficos, marcadores normales y sin clínica alguna (Figs. 1 y 2).

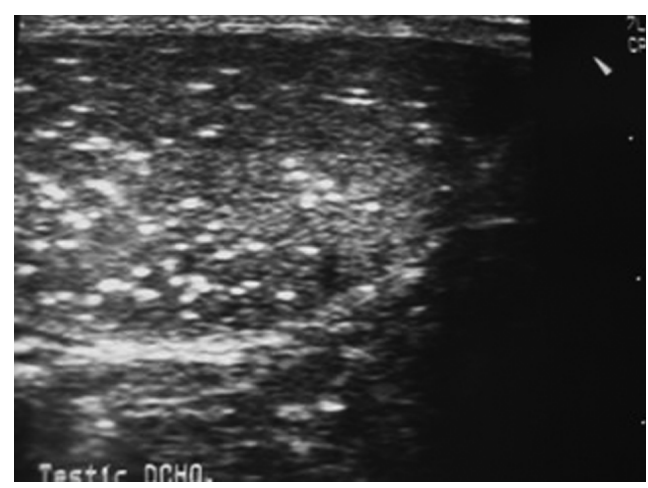

FIGURA 1. MT teste derecho.

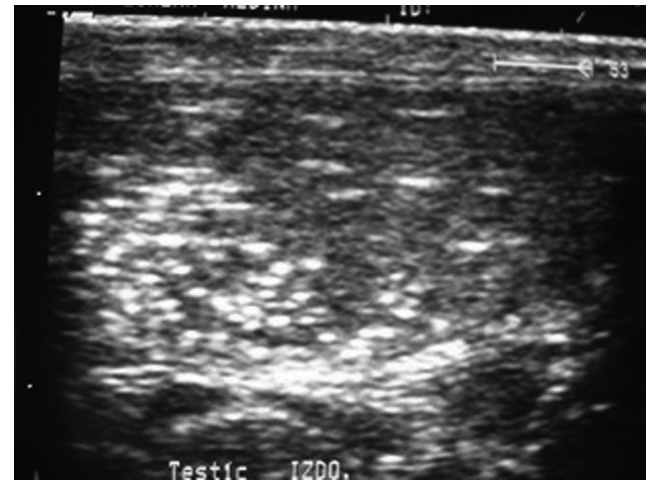

FIGURA 2. MT teste izquierdo.

\section{Caso 2}

Paciente de 30 años. Orquiectomia derecha hace 6 años por Ca embrionario, sin calcificaciones en testículo tumoral, pero si en el contralateral. Precisó quimioterapia por adenopatías retroperitoneales. Control ecográfico testicular, examen fisico y marcadores anualmente (Figs. 3 y 4), sin cambios en teste izquierdo y con MT de apariencia similar en todos los controles.

La MT es un hallazgo ultrasónico caracterizado por la presencia de 5 o más pequeñas imágenes hiperecógenicas, sin sombra acústica posterior, localizadas en el parénquima testicular, vistas por lo menos en un campo ultrasónico.
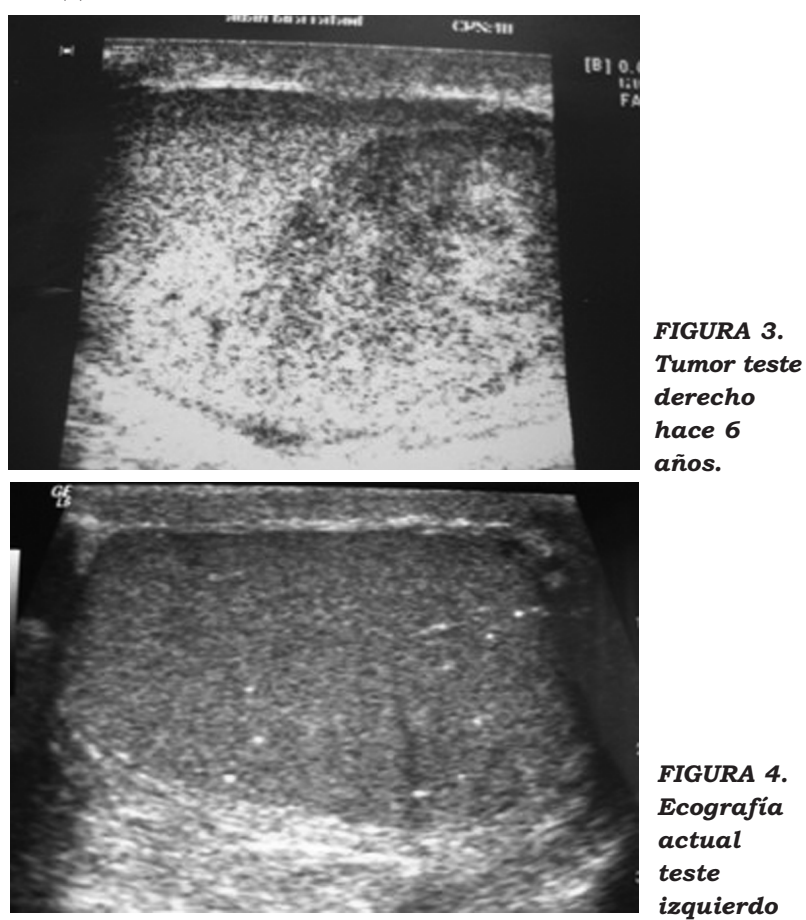

FIGURA 4. Ecografía actual teste izquierdo

No hay datos concluyentes que puedan afirmar o negar que la MT sea una lesión premaligna, pero para algunos autores podría considerarse como un marcador de la existencia de una lesión disgenética del parénquima gonadal que predispondría a la aparición de patología testicular tanto benigna como maligna. Se da en todas las edades, incluso en la pediátrica. Se asocia con más frecuencia en pacientes con criptorquidia, infertilidad, varicocele, torsión testicular, calcificaciones del sistema nervioso simpático y cerebro, pseudohermafroditismo, sindrome de Down, Klinefelter, Carney, fibrosis quística y tumores testiculares. Se estima que en la población asintomática pudiera darse hasta en el 5-6\%. La mayoria de autores aconsejan seguimiento de los pacientes con MT, semestralmente o anualmente con ecografia y marcadores, planteándose el interrogante de hasta cuando.

Correspondencia autor: Dr. H. Pastor Navarro

Servicio de Urología. Hospital General Universitario. Albacete Hermanos Falcó, s/n - 02006 Albacete

Tel.: 967597100

E-mail autor: hektorpn@hotmail.com

Información artículo: Imágenes en Urología

Trabajo recibido: septiembre 2006

Trabajo aceptado: octubre 2006 